\title{
New records for Anaplasma phagocytophilum infection in small mammal species
}

\author{
loana Adriana Matei ${ }^{1,2^{*}}$, Gianluca D’Amico', Angela Monica lonică' , Zsuzsa Kalmár ${ }^{1}$, Alexandra Corduneanu',
} Attila D. Sándor ${ }^{1}$, Nicodim Fiț ${ }^{2}$, Liviu Bogdan³ ${ }^{3}$ Călin M. Gherman ${ }^{1}$ and Andrei Daniel Mihalca ${ }^{1}$

\begin{abstract}
Background: Tick-borne diseases pose a major threat in public health. The epidemiological dynamics of these diseases depends on the tick vector species and their hosts, as well as the geographical distribution and ecology of both. Among many possible hosts for ticks, small mammals have a major role in the development of immature stages of several tick species. Small mammals are also important reservoir hosts for several pathogenic agents and possible reservoirs for Anaplasma phagocytophilum. In this context, the aim of our study was to evaluate the prevalence of $A$. phagocytophilum in small mammal species in Romania.

Results: A total of 791 small mammals of 31 species were tested by PCR, targeting the rrs gene for detection of $A$. phagocytophilum DNA. Positive results were obtained in 20 small mammals: five Apodemus flavicollis (6.49\%), three Sorex araneus (9.09\%), three A. uralensis (4.84\%), two A. sylvaticus (3.92\%), and one of each Spermophilus cittelus (7.14\%), Microtus agrestis (3.85\%), Sorex minutus (3.85\%), Muscardinus avellanarius (3.13\%), Crocidura suaveolens (2.44\%), Mus spicilegus (2\%) and M. arvalis (1.75\%).

Conclusions: Eleven small mammal species were found to be carriers of A. phagocytophilum, suggesting a possible involvement of these species in its epidemiology. To our knowledge, this is the first report of A. phagocytophilum in $S$. minutus, C. suaveolens, M. spicilegus, M. avellanarius and S. citellus.
\end{abstract}

Keywords: Anaplasma phagocytophilum, Small mammals, Prevalence, Romania

\section{Background}

Small mammals (Orders Rodentia and Eulipotyphla) represent a very diverse group of terrestrial vertebrates, with a worldwide distribution and usually represented by large populations $[1,2]$. They are highly adapted for various types of habitat, including urbanized areas, being a link between wild and anthropomorphic ecosystems through the frequent movement of these animals and their ticks between human dwellings and natural environments [3]. Fluctuations in their densities are very

\footnotetext{
* Correspondence: matei.ioana@usamvcluj.ro

'Department of Parasitology and Parasitic Diseases, Faculty of Veterinary Medicine, University of Agricultural Sciences and Veterinary Medicine, Cluj-Napoca, Romania

${ }^{2}$ Department of Microbiology, Immunology and Epidemiology, Faculty of Veterinary Medicine, University of Agricultural Sciences and Veterinary Medicine, Cluj-Napoca, Romania

Full list of author information is available at the end of the article
}

important factors of disease risk [4], playing an important role in the ecology of ticks and tick-borne diseases.

Small mammals are important hosts for several tick species, having an essential role in the development of immature stages of hard ticks, and also being essential maintenance hosts for the immature stages of Ixodes ricinus $[1,5]$. For instance, in a study focused on rodenttick associations in Romania, a high prevalence (over $50 \%$ ) of tick parasitism was found especially in Microtus arvalis, Apodemus uralensis, Apodemus flavicollis and Myodes glareolus [6]. Among the tick species found on small mammals in the Palaearctic, the genus Ixodes is the most well-represented: I. angustus, I. apronophorus, I. crenulatus, I. hexagonus, I. laguri, I. nipponensis, I. occultus, I. pomerantzevi, I. redikorzevi/I. acuminatus, I. ricinus and $I$. trianguliceps (reviewed in [1]). Even if some of these ticks are endophilic (nidicolous) (e.g. I. 
trianguliceps and I. acuminatus) and normally do not pose a direct public health hazard since they do not feed on humans, their co-occurrence with I. ricinus on the same host can lead to an exchange of pathogens among the different tick species [6]. From this point of view, small mammals are considered important bridge-hosts and pose an important risk for public health for numerous zoonotic pathogens [2]. Furthermore, rodents are often competent reservoirs for multi-host pathogens. For instance, mice (Muridae) and voles (Microtidae) are known to be important reservoirs for zoonotic agents like tick-borne encephalitis virus (TBEV), Borrelia afzelii, and "Candidatus Neoehrlichia mikurensis" [7]. The role of small mammals in the epidemiology of $A$. phagocytophilum in Europe is under debate, previously being considered important reservoir hosts [8]. Considering the high diversity and ubiquity of small mammals and the risk of human contact to their environment (nearly half of Romanian population live and work in rural areas and maintain close contact with nature [9]), the aim of this study was to evaluate the host and genetic diversity of $A$. phagocytophilum in small mammals in Romania.

\section{Methods}

\section{Small mammals trapping and sampling sites}

A total of 791 small mammals from 31 species were collected from a variety of habitats in 14 counties in Romania between 2010 and 2015, as previously described using snap traps [6]. The trapping of rodents was performed once per location in different months from late spring to early autumn when the vectors are active. In addition, other small mammals which were found dead, were collected from various sources. Whenever needed, research permits were obtained from competent authorities and ethical committees. Each captured or collected small mammal was identified to species level (according to [10]) and a necropsy was performed. Spleen tissue samples were collected from each animal. Ticks from the animals were removed and morphologically identified and published previously [6].

\section{DNA extraction}

Genomic DNA extraction was performed from the spleen tissue using ISOLATE II Genomic DNA Kit (Bioline, London, UK), following the manufacturer's instructions. For each extraction procedure, negative controls were used in order to identify possible crosscontamination. DNA from a representative number of samples was quantitatively analyzed using a Nanodrop ND-1000 spectrophotometer analyzer (Thermo Fisher Scientific Inc., Waltham, MA, USA).

\section{Polymerase chain reaction (PCR)}

The presence of $A$. phagocytophilum DNA in the spleen tissue was tested by a series of nested PCR assays using specific primers amplifying fragments of rrs (1st PCR: ge3a/ge10r; 2nd PCR: ge9f/ge2) [11]. The amplification was performed as follows: $25 \mu \mathrm{l}$ reaction mixture containing $12.5 \mu \mathrm{l}$ of Green PCR Master Mix (Rovalab $\mathrm{GmBH}$, Teltow, Germany), $6.5 \mu \mathrm{l}$ PCR water, $1 \mu \mathrm{l}$ of each primer $(0.01 \mathrm{mM})$ and $4 \mu \mathrm{l}$ aliquot of isolated DNA ( $1 \mu \mathrm{l}$ of the primary PCR for the nPCR). The amplification profile for $\mathrm{PCR}$ consisted of $5 \mathrm{~min}$ of initial denaturation at $95{ }^{\circ} \mathrm{C}$, followed by 40 cycles of denaturation at $94{ }^{\circ} \mathrm{C}$ for $30 \mathrm{~s}$, annealing at $55^{\circ} \mathrm{C}$ for $30 \mathrm{~s}$ and extension at $72{ }^{\circ} \mathrm{C}$ for $60 \mathrm{~s}$, and a final extension at $72^{\circ}$ $\mathrm{C}$ for $5 \mathrm{~min}$. For the $\mathrm{nPCR}$, the amplification profile consisted of $5 \mathrm{~min}$ of initial denaturation at $95{ }^{\circ} \mathrm{C}$, followed by 30 cycles of denaturation at $94{ }^{\circ} \mathrm{C}$ for $30 \mathrm{~s}$, annealing at $55{ }^{\circ} \mathrm{C}$ for $30 \mathrm{~s}$ and extension at $72{ }^{\circ} \mathrm{C}$ for 60 $\mathrm{s}$, and a final extension at $72{ }^{\circ} \mathrm{C}$ for $5 \mathrm{~min}$. In each PCR reaction set (48 samples), one positive and two negative controls were included in order to assess the specificity of the reaction and the possible presence of the presence cross-contamination. Positive controls consisted of DNA extracted from a tick positive for $A$. phagocytophilum previously confirmed by sequencing [12] and negative controls consisted in sterile water. The PCR was carried out using a $\mathrm{T}^{100^{\mathrm{T}}}$ Thermal Cycler (Bio-Rad, London, UK).

\section{Agarose gel electrophoresis}

PCR products were visualized by electrophoresis in a $1.5 \%$ agarose gel stained with $\mathrm{SYBR}^{\oplus}$ Safe DNA gel stain (Invitrogen, Carlsbad, CA, USA) and their molecular weight was assessed by comparison to a molecular marker (O'GeneRuler ${ }^{\text {Ts }} 100$ bp DNA Ladder, Thermo Fisher Scientific Inc., Waltham, MA, USA).

\section{DNA sequencing}

All positive PCR samples were sequenced. PCR products were purified from amplicons using the QIAquick PCR Purification Kit (Qiagen, Hilden, Germany). Sequencing analysis was performed (Macrogen Europe, Amsterdam, the Netherlands) and the obtained sequences were compared with those available in GenBank ${ }^{\text {TM }}$ by Basic Local Alignments Tool (BLAST) analysis.

\section{Statistical analysis}

Statistical analysis was performed using Epi $\operatorname{Info}^{\mathrm{Tm}} 7$ (CDC, Atlanta, GA, USA) software. The total infection prevalence of $A$. phagocytophilum (95\% CI), the infection prevalence per species and group of species and the infection prevalence in each county was assessed using the Chi-square independence test. A $P$-value less than 0.05 was considered significant. 


\section{Results}

Twenty out of 791 small mammals were positive for $A$. phagocytophilum DNA presence with an overall prevalence of $2.53 \%$ (95\% CI: $1.59-3.95 \%)$. The small mammal species found positive were: S. araneus $(9.09 \%, 95 \%$ CI: 1.92-24.33\%), S. cittelus (7.14\%, 95\% CI: 0.18-33.87\%), A. flavicollis (6.49\%, 95\% CI: 2.14-14.51\%), A. uralensis (4.84\%, 95\% CI: 1.01-13.5\%), A. sylvaticus (3.92\%, 95\% CI: $0.48-13.46 \%), M$. agrestis (3.85\%, 95\% CI: $0.10-$ 19.64\%), S. minutus (3.85\%, 95\% CI: 0.10-19.64\%), M. avellanarius (3.13\%, 95\% CI: 0.08-16.22\%), C. suaveolens (2.44\%, 95\% CI: 0.06-12.86\%), Mus spicilegus (2\%, 95\%
CI: $0.05-10.65 \%)$ and M. arvalis (1.75\% ; 95\% CI: $0.04-$ 9.39\%) (Table 1). No statistically significant differences in prevalence were observed between different small mammal species, nor between taxonomic groups: mice (3.06\%, 95\% CI: $1.61-5.56 \%)$, voles $(1.14 \%$, 95\% CI: 0.14-4.07\%), shrews (3.94\%, 95\% CI: $1.28-8.95 \%)$ dormice $(1.33 \%$, 95\% CI: $0.03-7.21 \%)$, or squirrels $(6.67 \%$, 95\% CI: 0.17-31.95\%).

The positive small mammals originated from Tulcea (6/118; 4.84\%, 95\% CI: 1.80-10.23\%), Constanța (6/153; 3.77\%; 95\% CI: $1.40-8.03 \%$ ), Mureș (4/111; 3.48\%; 95\% CI: $0.96-8.67 \%)$, Cluj (2/217; 0.92\%; 95\% CI: $0.11-$

Table 1 Prevalence of A. phagocytophilum in small mammal species

\begin{tabular}{|c|c|c|c|}
\hline & Species & Counties & Positive/Total \\
\hline \multirow[t]{2}{*}{ Dormouse } & Glis glis & $C V$ & $0 / 43$ \\
\hline & Muscardinus avellanarius & $\mathrm{CJ}, \mathrm{CV}, \mathrm{MS}$ & $1 / 32$ \\
\hline Hamster & Cricetus cricetus & CJ, MS & $0 / 3$ \\
\hline Mole & Talpa europaea & $\mathrm{BH}, \mathrm{BZ}, \mathrm{CJ}, \mathrm{CV}, \mathrm{MS}, \mathrm{SJ}, \mathrm{TL}$ & $0 / 14$ \\
\hline Mole-rat & Spalax leucodon & $\mathrm{TL}$ & $0 / 3$ \\
\hline \multirow[t]{7}{*}{ Mouse } & Apodemus agrarius & $\mathrm{BC}, \mathrm{CJ}, \mathrm{CT}, \mathrm{CV}, \mathrm{MS}$ & $0 / 60$ \\
\hline & Apodemus flavicollis & $\mathrm{BC}, \mathrm{CJ}, \mathrm{HR}, \mathbf{M S}, \mathbf{T L}$ & $5 / 77$ \\
\hline & Apodemus sylvaticus & $\mathrm{CJ}, \mathrm{CT}, \mathrm{CV}, \mathrm{HR}, \mathrm{MS}, \mathrm{TL}$ & $2 / 51$ \\
\hline & Apodemus uralensis & $\mathrm{CT}, \mathrm{HR}, \mathrm{MS}, \mathrm{TL}$ & $3 / 62$ \\
\hline & Micromys minutus & $C J, C T, T L$ & $0 / 5$ \\
\hline & Mus musculus & $\mathrm{AB}, \mathrm{BH}, \mathrm{CJ}, \mathrm{CV}, \mathrm{HR}, \mathrm{TL}$ & $0 / 55$ \\
\hline & Mus spicilegus & $\mathrm{BC}, \mathrm{CJ}, \mathrm{CT}, \mathrm{TL}$ & $1 / 50$ \\
\hline Muskrat & Ondatra zibethicus & $\mathrm{BV}, \mathrm{TL}$ & 0/9 \\
\hline Rat & Rattus norvegicus & $A B, C J, C T, H R, M S$ & $0 / 10$ \\
\hline \multirow[t]{7}{*}{ Shrew } & Crocidura leucodon & $C J, C T, M S, T L$ & $0 / 21$ \\
\hline & Crocidura suaveolens & $C J, C T, C V, M S, T L$ & $1 / 41$ \\
\hline & Neomys anomalus & $C T, T L$ & $0 / 3$ \\
\hline & Neomys fodiens & $C T, M S$ & $0 / 2$ \\
\hline & Sorex alpinus & $\mathrm{BH}$ & $0 / 1$ \\
\hline & Sorex araneus & $\mathrm{AG}, \mathrm{CJ}, \mathrm{CV}, \mathbf{H R}, \mathbf{M S}$ & $3 / 33$ \\
\hline & Sorex minutus & $C J, C T, C V, H R, M S, T L$ & $1 / 26$ \\
\hline \multirow[t]{2}{*}{ Squirrel } & Sciurus vulgaris & BV & $0 / 1$ \\
\hline & Spermophilus citellus & $\mathrm{BT}, \mathrm{CT}, \mathrm{TL}$ & $1 / 14$ \\
\hline \multirow[t]{7}{*}{ Vole } & Arvicola amphibius & $C T$ & $0 / 1$ \\
\hline & Arvicola scherman & $\mathrm{BH}$ & $0 / 1$ \\
\hline & Microtus agrestis & CJ, HR, TL & $1 / 26$ \\
\hline & Microtus arvalis & $\mathrm{BV}, \mathrm{CJ}, \mathrm{CT}, \mathrm{CV}, \mathrm{MS}, \mathrm{TL}$ & $1 / 57$ \\
\hline & Microtus subterraneus & $C J, H R, M S$ & $0 / 36$ \\
\hline & Microtus tatricus & $H R$ & $0 / 1$ \\
\hline & Myodes glareolus & $\mathrm{CJ}, \mathrm{CV}, \mathrm{HR}, \mathrm{MS}$ & $0 / 53$ \\
\hline
\end{tabular}

Bold indicates positive samples, hosts and counties with positive animals detected Abbreviations: AB Alba, AG Argeş, BC Bacău, BT Botoşani, BH Bihor, BV Brașov, BZ Buzău, CJ Cluj, CT Constanța, CV Covasna, HR Harghita, MS Mureş, SJ Sălaj, TL Tulcea 
3.29\%), Harghita (1/27; 3.57\%; 95\% CI: $0.09-18.35 \%)$ and Covasna (1/124; $0.8 \%$; 95\% CI: $0.02-4.38 \%)$, without significance difference between the counties.

The presence of A. phagocytophilum was confirmed by sequence analysis with all the sequences $(n=20)$ showing $99-100 \%$ similarity to strains from dogs in Germany and ticks in Belarus and Russia, respectively (GenBank: JX173651, HQ629911, HQ629915). The sequence analysis has shown a small degree of variability with only one up to three nucleotides different between the strains (Additional file 1).

\section{Discussion}

The aim of present study was to evaluate the host spectrum and prevalence of A. phagocytophilum in small mammal species across Romania. The results have shown an overall low prevalence, with no significant difference between host species and geographical areas. The low genetic diversity and the large number of positive species from our study confirm the low host specificity of A. phagocytophilum observed at least for some variants [13].

Anaplasma phagocytophilum DNA was previously detected in several small mammal species such as $A$. agrarius, A. flavicollis, A. uralensis, A. sylvaticus, $M$. musculus, $M$. agrestis, $M$. arvalis, $M$. oeconomus, Myodes glareolus, S. araneus and C. russula in several European countries $[8,13-29]$. There are also several reports on the occurrence of A. phagocytophilum infection in Erinaceus europaeus [30-32], E. roumanicus [33] and Rattus rattus [15] and in large rodents such as Hystrix cristata [34]. In addition to small mammals, $A$. phagocytophilum was detected in a large variety of hosts including birds, domestic and wild carnivores, livestock, wild ruminants, wild boars and humans (reviewed in [13]). To our knowledge, this is the first report of $A$. phagocytophilum in S. minutus, C. suaveolens, M. spicilegus, $M$. avellanarius and S. citellus.

The overall prevalence in small mammals in the present study was within the prevalence intervals from other reports (reviewed in [13]). The A. phagocytophilum prevalence recorded in other European countries present a high variability especially for several species such as: $A$. agrarius $(1.28-13.54 \%)$ [24, 35], A. flavicollis $(0.48-18 \%)$ $[22,36]$, A. sylvaticus $(0.61-11.1 \%)[19,20], M$. agrestis $(0.28-25 \%)[37,38], M$. arvalis $(0.28-25 \%)[29,37]$ and M. glareolus $(0.30-21.85 \%)[25,28]$. In the present study, prevalence of $A$. phagocytophilum in A. flavicollis (6.49\%) was lower than in the Czech Republic [16] and higher than in Germany and Switzerland [8, 22]. Apodemus sylvaticus from Romania was less infected than A. flavicollis, in contrast with results obtained in Switzerland [8]. Anaplasma phagocytophilum was previously found in one A. uralensis in Slovakia, having a similar prevalence
(5.6\%) with that obtained in our study [23]. The A. phagocytophilum prevalence found in $M$. agrestis, $M$. arvalis and $S$. araneus was lower than in Germany, the UK and Switzerland [8, 23, 39]. A higher prevalence in S. araneus than in Apodemus spp. was observed in our study, similar with the results from the UK and Switzerland $[8,40]$. Our results have shown no A. phagocytophilum in M. glareolus, while in the majority of studies the bank vole is frequently more infected compared with rodents $[8,23$, $26,36]$. Furthermore, in the studies focused on the bank vole, the obtained prevalence ranged between 5 and $22 \%$ $[14,28]$. The differences in prevalence between different studies could be explained by several factors such as abundance and population structure of the tick vector and the abundance and diversity of potential reservoir hosts, both being influenced by the climatic and ecological features including sampling period. Others factors which may influence the prevalence are related to the type and quality of samples and methods used. Conservative strategies are usually used for screening based on rrs and groEL genes or multicopy of the major surface proteins such as msp2 and msp4 (reviewed in [41]). Among different types of samples, our previous research and literature data suggest spleen tissue as the most suitable organ for the detection of A. phagocytophilum [41].

Small mammals were previously considered reservoir hosts for A. phagocytophilum [8]. They are important hosts for immature stages of I. ricinus [42], and also for I. trianguliceps [38] and I. hexagonus [30], which may transmit the infection. However, since most rodents are short-lived animals and that the infection with $A$. phagocytophilum seems to be transient [30], their role as suitable reservoir hosts is currently under debate. Moreover, in recent years it has been suggested that small mammals and their ticks are involved in a separate enzootic cycle. This hypothesis is sustained by the phylogenetic analysis on ankA and groEL genes which showed that strains isolated from small mammals differ genetically from those circulating in I. ricinus ticks, domestic ruminants, wild boar, dogs, horses or humans [26, 28, 39, 43]. It has been suggested that $I$. trianguliceps might be the vector of these rodent strains in the UK [39, 40]. Furthermore, in Switzerland and Slovakia, A. phagocytophilum was not detected in I. ricinus ticks feeding on rodents even though $A$. phagocytophilum was detected in questing I. ricinus in the same areas [44] or in I. trianguliceps removed from the same hosts [26]. Moreover, none of the artificially-fed $I$. ricinus became infected after engorging blood from positive rodents [44]. However, more experimental studies, including xenodiagnostics are needed to confirm this separate enzootic cycle. Although the sequence analysis confirmed the presence of $A$. phagocytophilum DNA in small mammal species, experimental studies are required to demonstrate the 
role of these species as competent host. Moreover, the rrs gene is highly conservative and further research on other genes or by more sensitive techniques such as multilocus sequence typing (MLST) or multilocus variable-number tandem-repeat analysis (MLVA), is needed in order to properly characterize these strains present in small mammals in Romania. Based on the data obtained in this study it is unclear if these strains are hazardous to humans or domestic animals and if they are transmitted by public health relevant tick species.

\section{Conclusions}

Several small mammal species are described in the literature as carriers of $A$. phagocytophilum. Besides these, our results have shown other species such as $S$. minutus, C. suaveolens, M. spicilegus, M. avellanarius and S. citellus, which can also be infected with A. phagocytophilum. However, it is unclear whether these animals can act as competent reservoir hosts and for which $A$. phagocytophilum variants.

\section{Additional files}

Additional file 1: Alignment of the sequences obtained in this study. Nucleotides different between the strains are marked with different colors. (DOCX $19 \mathrm{~kb})$

\section{Abbreviations}

BLAST: Basic Local Alignments Tool; MLST: Multilocus sequence typing; MLVA: Multilocus variable-number tandem-repeat analysis; nPCR: Nested PCR; rrs: 165 rRNA

\section{Acknowledgments}

The abstract of this paper has been presented at a local student symposium by an undergraduate student, Emese Beáta Tamás, to whom we want to thank for her contribution.

\section{Funding}

The research was supported from grant PN-II-RU-TE-2014-4-0919: TE/298/

2015. This paper was published under the frame of EurNegVec COST Action TD1303.

\section{Availability of data and materials}

The data supporting the conclusions of this article are included within the article. Raw data used and/or analyzed during the current study are available from the corresponding author upon reasonable request.

\section{Authors' contributions}

GDA, ADS, NF, LB, CMG and ADM collected the small mammals. IAM and AMI performed the necropsy. IAM and ZK performed DNA extraction. IAM conducted DNA detection by PCR. IAM and AC performed agar gel electrophoresis. IAM analyzed and interpreted statistical analysis and wrote the manuscript. GDA and ADM were major contributors in writing the manuscript. All authors read and approved the final manuscript.

\section{Ethics approval}

This study was approved by the USAMV CN Bioethics Committee with the registration number 23/ 21-09-2015, following the EU 2010/63 and National directives Ord. 28/31-08-2011 and National Law 206/2004.

\section{Consent for publication}

Not applicable.

\section{Competing interests}

The authors declare that they have no competing interests.

\section{Publisher's Note}

Springer Nature remains neutral with regard to jurisdictional claims in published maps and institutional affiliations.

\section{Author details}

'Department of Parasitology and Parasitic Diseases, Faculty of Veterinary Medicine, University of Agricultural Sciences and Veterinary Medicine, Cluj-Napoca, Romania. ${ }^{2}$ Department of Microbiology, Immunology and Epidemiology, Faculty of Veterinary Medicine, University of Agricultural Sciences and Veterinary Medicine, Cluj-Napoca, Romania. ${ }^{3}$ Department of Reproduction, Obstetrics and Pathology of Animal Reproduction, Faculty of Veterinary Medicine, University of Agricultural Sciences and Veterinary Medicine, Cluj-Napoca, Romania.

Received: 4 January 2018 Accepted: 8 March 2018

Published online: 20 March 2018

\section{References}

1. Durden LA. Taxonomy, host associations, life cycles and vectorial importance of ticks parasitizing small mammals. In: Morand S, Krasnov BR, Poulin R, editors. Micromammals and macroparasites: From evolutionary ecology to management. Tokyo: Springer-Verlag; 2006. p. 91-102.

2. Gratz N. Vector-and rodent-borne diseases in Europe and North America: Distribution, public health burden, and control. Cambridge: Cambridge University Press; 2006.

3. Gage KL, Kosoy MY. Non-commensal rodents and lagomorphs. In: Bonnefoy $\mathrm{X}$, Kampen $\mathrm{H}$, Sweeney K, editors. Public health significance of urban pests. Copenhagen: World Health Organization; 2008. p. 421-76.

4. Heyman P, Cochez C, Hofhuis A, Van Der Giessen J, Sprong H, Porter SR, et al. A clear and present danger: tick-borne diseases in Europe. Expert Rev Anti-Infect Ther. 2010;8(1):33-50.

5. Mihalca AD, Sándor AD. The role of rodents in the ecology of Ixodes ricinus and associated pathogens in central and eastern Europe. Front Cell Infect Microbiol. 2013;3:56.

6. Mihalca AD, Dumitrache MO, Sándor AD, Magdaş C, Oltean M, Györke A, et al. Tick parasites of rodents in Romania: host preferences, community structure and geographical distribution. Parasit Vectors. 2012;5:266.

7. Rizzoli A, Silaghi C, Obiegala A, Rudolf I, Hubálek Z, Földvári G, et al. Ixodes ricinus and its transmitted pathogens in urban and peri-urban areas in Europe: new hazards and relevance for public health. Front Public Health. 2014;2:251.

8. Liz JS, Anderes L, Sumner JW, Massung RF, Gern L, Rutti B, Brossard M. PCR detection of granulocytic ehrlichiae in Ixodes ricinus ticks and wild small mammals in western Switzerland. J Clin Microbiol. 2000;38(3):1002-7.

9. Vincze M, Kerekes K. Impact of CAP's pillars on Romanian rural employment. In: Proceedings of the Aspects and Visions of Applied Economics and Informatics Conference, Debrecen, 2009:4:68-73.

10. Mitchell-Jones AJ, Moutou F, Zima J. Mammals of Europe, North Africa and the Middle East. London: A\&C Black; 2009.

11. Massung RF, Slater K, Owens JH, Nicholson WL, Mather TN, Solberg VB, Olson JG. Nested PCR assay for detection of granulocytic ehrlichiae. J Clin Microbiol. 1998;36(4):1090-5.

12. Matei IA, Kalmár Z, Lupşe M, D'Amico G, Ionică AM, Dumitrache MO, et al. The risk of exposure to rickettsial infections and human granulocytic anaplasmosis associated with Ixodes ricinus tick bites in humans in Romania: a multiannual study. Ticks Tick Borne Dis. 2017;8(3):375-8.

13. Stuen S, Granquist EG, Silaghi C. Anaplasma phagocytophilum - a widespread multi-host pathogen with highly adaptive strategies. Front Cell Infect Microbiol. 2013;3:31.

14. Bown K, Begon M, Bennett M, Woldehiwet Z, Ogden NH. Seasonal dynamics of Anaplasma phagocytophila in a rodent-tick (Ixodes trianguliceps) system, United Kingdom. Emerg Infect Dis. 2003;9(1):63-70.

15. Christova I, Gladnishka T. Prevalence of infection with Francisella tularensis, Borrelia burgdorferi sensu lato and Anaplasma phagocytophilum in rodents from an endemic focus of tularemia in Bulgaria. Ann Agric Environ Med. 2004;12(1):149-52. 
16. Hulínská D, Langrová K, Pejčoch M, Pavlasek I. Detection of Anaplasma phagocytophilum in animals by real-time polymerase chain reaction. APMIS. 2004;112(4-5):239-47.

17. Smetanová K, Schwarzová K, Kocianová E. Detection of Anaplasma phagocytophilum, Coxiella burnetii, Rickettsia spp., and Borrelia burgdorferi s.l. in Ticks, and wild-living animals in Western and Middle Slovakia. Ann N Y Acad Sci. 2006;1078(1):312-5.

18. Grzeszczuk A, Karbowiak G, Ziarko S, Kovalchuk O. The root-vole Microtus oeconomus (Pallas, 1776): a new potential reservoir of Anaplasma phagocytophilum. Vector Borne Zoonotic Dis. 2006;6(3):240-3.

19. Barandika JF, Hurtado A, García-Esteban C, Gil H, Escudero R, Barral M, et al. Tick-borne zoonotic bacteria in wild and domestic small mammals in northern Spain. Appl Environ Microbiol. 2007;73(19):6166-71.

20. Bray DP, Bown KJ, Stockley P, Hurst JL, Bennett M, Birtles RJ. Haemoparasites of common shrews (Sorex araneus) in northwest England. Parasitology. 2007;134(06):819-26.

21. Matsumoto $\mathrm{K}$, Joncour G, Lamanda $\mathrm{P}$, Inokuma H, Brouqui P. Detection of Anaplasma phagocytophilum and Ehrlichia sp. HF strains in Ixodes ricinus ticks in Brittany, France. Clin Microbiol Infect. 2007;13(3):338-41.

22. Hartelt K, Pluta S, Oehme R, Kimmig P. Spread of ticks and tick-borne diseases in Germany due to global warming. Parasitol Res. 2008;103(1):109-16.

23. Štefančíková $A$, Derdáková $M$, Lenčáková $D$, Ivanová $R$, Stanko $M$, Čisláková L, Pet'ko B. Serological and molecular detection of Borrelia burgdorferi sensu lato and Anaplasmataceae in rodents. Folia Microbiol. 2008;53(6):493-9.

24. Krücken J, Schreiber C, Maaz D, Kohn M, Demeler J, Beck S, et al. A novel high-resolution melt PCR assay discriminates Anaplasma phagocytophilum and "Candidatus Neoehrlichia mikurensis". J Clin Microbiol. 2013;51:1958-61.

25. Baráková I, Derdáková M, Carpi G, Rosso F, Collini M, Tagliapietra V, et al. Genetic and ecologic variability among Anaplasma phagocytophilum strains, northern Italy. Emerg Infect Dis. 2014;20(6):1082-5.

26. Blaňarová L, Stanko M, Carpi G, Miklisová D, Víchová B, Mošanský L, et al. Distinct Anaplasma phagocytophilum genotypes associated with Ixodes trianguliceps ticks and rodents in central Europe. Ticks Tick Borne Dis. 2014; 5(6):928-38.

27. Jahfari S, Coipan EC, Fonville M, Van Leeuwen AD, Hengeveld P, Heylen D, et al. Circulation of four Anaplasma phagocytophilum ecotypes in Europe. Parasit Vectors. 2014;7:365.

28. Kallio ER, Begon M, Birtles RJ, Bown KJ, Koskela E, Mappes T, Watts PC. First report of Anaplasma phagocytophilum and Babesia microti in rodents in Finland. Vector-Borne Zoonotic Dis. 2014;14(6):389-93.

29. Szekeres S, Coipan EC, Rigó K, Majoros G, Jahfari S, Sprong H, Földvári G. "Candidatus Neoehrlichia mikurensis" and Anaplasma phagocytophilum in natural rodent and tick communities in Southern Hungary. Ticks Tick Borne Dis. 2015;6(2):111-6.

30. Skuballa J, Petney T, Pfäffle M, Taraschewski H. Molecular detection of Anaplasma phagocytophilum in the European hedgehog (Erinaceus europaeus) and its ticks. Vector-Borne Zoonotic Dis. 2010;10(10):1055-7.

31. Silaghi C, Skuballa J, Thiel C, Pfister K, Petney T, Pfäffle M, et al. The European hedgehog (Erinaceus europaeus) - a suitable reservoir for variants of Anaplasma phagocytophilum? Ticks Tick Borne Dis. 2012;3(1):49-54.

32. Huhn C, Winter C, Wolfsperger T, Wüppenhorst N, Smrdel KS, Skuballa $J$, et al. Analysis of the population structure of Anaplasma phagocytophilum using multilocus sequence typing. PLoS One. 2014 9(4):e93725

33. Földvári G, Rigó K, Jablonszky M, Biró N, Majoros G, Molnár V, Tóth M. Ticks and the city: ectoparasites of the Northern white-breasted hedgehog (Erinaceus roumanicus) in an urban park. Ticks Tick Borne Dis. 2011;2(4):231-4.

34. Torina A, Alongi A, Naranjo V, Estrada-Peña A, Vicente J, Scimeca S, et al. Prevalence and genotypes of Anaplasma species and habitat suitability for ticks in a Mediterranean ecosystem. Appl Environ Microbiol. 2008;74(24): 7578-84.

35. Christova I, Dimitrov H, Trifonova I, Gladnishka T, Mitkovska V, Stojanova A, et al. Detection of human tick-borne pathogens in rodents from Bulgaria. Acta Zool Bulg. 2012;64(Suppl. 4):111-4.

36. Chastagner A, Moinet M, Perez G, Roy E, McCoy KD, Plantard O, et al. Prevalence of Anaplasma phagocytophilum in small rodents in France. Ticks Tick Borne Dis. 2016;7(5):988-91.

37. Obiegala A, Pfeffer M, Pfister K, Tiedemann T, Thiel C, Balling A, et al. "Candidatus Neoehrlichia mikurensis" and Anaplasma phagocytophilum: prevalences and investigations on a new transmission path in small mammals and ixodid ticks. Parasit Vectors. 2014;7:563.
38. Bown KJ, Begon M, Bennett M, Birtles RJ, Burthe S, Lambin X, et al. Sympatric Ixodes trianguliceps and Ixodes ricinus ticks feeding on field voles (Microtus agrestis): potential for increased risk of Anaplasma phagocytophilum in the United Kingdom? Vector Borne Zoonotic Dis. 2006:6:404-10.

39. Bown KJ, Lambin X, Telford GR, Ogden NH, Telfer S, Woldehiwet Z, Birtles RJ. Relative importance of Ixodes ricinus and Ixodes trianguliceps as vectors for Anaplasma phagocytophilum and Babesia microti in field vole (Microtus agrestis) populations. Appl Environ Microbiol. 2008;74(23):7118-25.

40. Bown KJ, Lambin X, Ogden NH, Begon M, Telford G, Woldehiwet Z, Birtles RJ. Delineating Anaplasma phagocytophilum ecotypes in coexisting, discrete enzootic cycles. Emerg Infect Dis. 2009;15(12):1948-54.

41. Silaghi C, Santos AS, Gomes J, Christova I, Matei IA, Walder G, et al. Guidelines for the direct detection of Anaplasma spp. in diagnosis and epidemiological studies. Vector Borne Zoonotic Dis. 2017;17(1):12-22.

42. Nilsson A. Seasonal occurrence of Ixodes ricinus (Acari) in vegetation and on small mammals in southern Sweden. Ecography. 1988;11(3):161-5.

43. Majazki J, Wüppenhorst N, Hartelt K, Birtles R, Von Loewenich FD. Anaplasma phagocytophilum strains from voles and shrews exhibit specific ankA gene sequences. BMC Vet Res. 2013;9(1):235.

44. Burri C, Schumann O, Schumann C, Gern L. Are Apodemus spp. mice and Myodes glareolus reservoirs for Borrelia miyamotoi, "Candidatus Neoehrlichia mikurensis", Rickettsia helvetica, R. monacensis and Anaplasma phagocytophilum? Ticks Tick Borne Dis. 2014;5(3):245-51.

\section{Submit your next manuscript to BioMed Central and we will help you at every step:}

- We accept pre-submission inquiries

- Our selector tool helps you to find the most relevant journal

- We provide round the clock customer support

- Convenient online submission

- Thorough peer review

- Inclusion in PubMed and all major indexing services

- Maximum visibility for your research

Submit your manuscript at www.biomedcentral.com/submit
) Biomed Central 